\title{
Analisis Komponen Biaya Terhadap Pendapatan Bisnis Online Shop (Studi Kasus Pada Bisnis Online Shop Kota Surakarta)
}

\author{
Totok Susilo Pamuji Nugroho
}

STIE Atma Bhakti Surakarta

Email : tosiepamuji@gmail.com

\begin{abstract}
This study aims to determine the cost components needed to generate maximum income in the online shop business from January to June 2021. In order to generate maximum income, there are certainly many factors that must be considered. The population of this study is online business people in Surakarta, totaling 65 people, the sample selection criteria are online business people who earn below 100 million rupiah per year. Data collection techniques in this study are interviews and documentation. The results of this study indicate that the cost of expeditions, raw material costs and labor costs have a positive and significant impact on online shop business income in the city of Surakarta. Simultaneous test results also prove that expedition costs, raw material costs and labor costs also have a positive and significant effect on online shop business income in the city of Surakarta.
\end{abstract}

Keywords: Online Shop, Expedition costs, Raw Material costs, Labor costs

\section{PENDAhULUAN}

Di dalam suatu bisnis pastinya para pelaku usaha mengupayakan pendapatan secara maksimal pada bisnisnya, entah apapun jenis usahanya. Hal ini merupakan hal yang wajar karena untuk keberlangsungan hidup para pelaku bisnis dan para karyawan sangat memerlukan pendapatan (Shah, 2018). Akan tetapi untuk memaksimalkan pendapatan pada dunia bisnis memang tidaklah semudah membalikkan telapak tangan. Banyak sekali hal-hal yang harus diperhatikan, dicermati dan dilaksanakan secara rutin dan menyeluruh. Para pelaku bisnis kadang kalanya bisa gagal dalam hal menjalankan strategi bisnisnya, oleh karena itu tekad baja sangat diperlukan dalam menjalankan bisnisnya (Nugroho, 2018)

Mempunyai tekad yang kuat sekeras baja sangalah diperlukan dalam menjalankan bisnis online shop sekarang ini. Hal ini dikarenakan dalam bisnis pasri banyak sekali permasalahan yang timbul, misalnya bahan baku tidak sesuai ekspektasi, pesanan pelanggan kurang memuaskan, dll (Johansson, 2020). Oleh karena itu inovasi dalam mencapai pendapatan yang maksimal sangat dibutuhkan, jadi tanpa inovasi maka produknya kan dianggap sama dan pasaran sehingga pelanggan tidak akan tertarik. Mempunyai produk sendiri dan memiliki daya tarik tersendiri sangatlah diperlukan dalam pengembangan bisnis online shop terlebih lagi dalam rangka untuk mendongkrak pendapatan secara maksimal (Haus, 2019)

Para pelaku bisnis online pastinya juga berupaya untuk mendapatkan penghasilan secara maksimal. Dalam rangka untuk mendapatkan hal ini tentu saja banyak rintangan yang akan dihadapi, apalagi saat ini sedang sangat marak dalam hal bisnis online (Weldy, 2018). Pada era sekarang ini banyak sekali marketplace yang bisa menjadi tempat berjualan seperti : shopee, lazada, bukalapak, tokopedia, dll. Media sosialpun juga tak luput digunakan sebagai sarana berjualan baik itu melalui facebook, instagram, twiter dll. Hal ini membuktikan bahwa dewasa ini bisnis online lebih banyak diminati, sehingga semakin banyak pelaku bisnis menggunakan bisnis online otomatis semakin banyak pula pesaingnya (Alalwan, 2017).

Dalam hal untuk menunjung penjualan para pelaku bisnis online di kota Surakarta tentunya ada komponen-komponen biaya utama dan penunjang yang di perlukan untuk memaksimalkan hasilnnya (Apple, 2020). .Komponen biaya ini sangat diperlukan agar bisa memksimalkan omset penjualannya, sehingga menghasilkan pendapatan yang besar tiap bulannya . Biaya-biaya yang diperlukan antara lain biaya ekspedisi, biaya bahan baku, biaya produksi dan biaya tenaga kerja, dll. Akan tetapi dalam penelitian ini yang akan menjadi pembahasan adalah keempat komponen biaya tersebut (Palmer, 2018). Hal ini dikarenakan keempat komponen biaya tersebut sangatlah diperlukan dan menjadi inti dari bisnis online shop sekarang ini.

Biaya Ekspedisi diperlukan dalam rangka mengirimkan barang dari suatu daerah kedaerah lain yang letaknya dekat maupun berjualan. Dikarenakan online shop tidak atau belum mempunyai toko offline sendiri, sehingga hal ini yang paling dimungkinkan bisa dilakukan, sehingga biaya ini sangat penting sekali dan tidak tergantikan (Koziel, 2017). Biaya ekspedisi ini biasanya dibebankan ke customer atau mungkin ada perjanjian khusus antara pembeli dan penjual yang mungkin saja ada gratis ongkos kirim (ongkir) ataupun adanya subsidi ongkir. Ekspedisi di Indonesia saat ini sangat banyak sekali baik yang melayani partai ecer maupun partai besar (cargo), dimana sekarang pihak ekspedisi bersaing sangat ketat guna mendapatkan pelanggan semaksimal mungkin. Ekspedisi yang dimaksudkan sepeti JnT Ekspress, JNE, Wahana, Pos, Tiki dan lain-lain (Sari, 2019). 
Jenis biaya yang kedua adalah bahan baku, ini merupakan biaya utama dalam perusahaan apapun. Demikian pula untuk bisnis online shop juga memperlukan biaya ini sebagai langkah awal dalam memulai bisnisnya (Susanto, 2018). Misalnya online shop yang menjual pakaian otomatis toko ini harus membeli kain sebagai bahan bakunya, baru kemudian dia memikirkan mau dibawa ke konveksi mana untuk dijahit kain tersebut. Biaya ini memang sangat vital sekali dan harus diperhitungkan, pelaku bisnis harus dengan cermat memikirkan bahan baku jenis apa yang saat itu dibutuhkan, jangan sampai salah dalam pemilihan bahan baku. Disamping itu pelaku bisnis juga harus memperhatikan kualitasnya, karena untuk menghasilkan barang yang berkualitas juga memerlukan bahan baku yang berkualitas pula (Ernawati, 2018).

Biaya yang diperlukan yang ketiga adalah biaya produksi , jenis biaya ini sangat penting dan tidak akan pernah tergantikan. Dengan adanya biaya produksi maka bahan baku bisa diolah menjadi barang jadi dan siap pakai (Tosello, 2019). Disamping itu biaya ini juga dapat digunakan sebagai tolak ukur atas pendapatan dan pengeluaran, sehingga apabila seorang pelaku usaha salah memperhitungkannya dan tidak akurat maka akan berakibat timbulnya suatu kerugian serta masalah produksi lainnya. Biaya produksi ini erat sekali kaitannya dengan anggaran belanja bagi pelaku usaha, sehingga benar-benar harus diperhatikan, dicermati dan diteliti (Rosdiana, 2020)

Komponen biaya selanjutnya yang sangat diperlukan dalam bisnis online shop adalah biaya tenaga kerja. Jenis biaya ini juga sangat penting sekali untuk diperhatikan, hal ini dikarenakan apabila usaha seseorang sudah besar maka dia tidak mungkin bisa untuk mengurus usahanya sendiri, sehingga membutuhkan seorang atau beberapa karyawan (Pakkanen, 2020). Jenis biaya ini juga erat sekali kaitannya dengan biaya produksi dimana digunakan sebagai salah satu penentu kebijakan dalam suatu bisnis, pengawasa akan tumbuh kembangnya suatu usaha serta digunakan sebagai penentu dalam menyelesaikan persoala-persoalan dalam suatu proses bisnis (Situmeang, 2018). Sehingga dari paparan diatas penulis sangat tertarik sekali membahas topik ini, oleh karena itu judul yang akan di ambil adalah Analisis Komponen Biaya Terhadap Pendapatan Bisnis Online Shop (Studi Kasus Pada Bisnis Online Shop Kota Surakarta)

\section{Teori Keagenan (Agency Theory)}

Terdapat dua belah pihak dimana prinipnya tidak selalu sama dan bahkan sering bertentangan yakni agen dan principal, kedua pelaku ekonomi ini yang dibahas dalam teori keagenan. Teori keagenan ini adalah suatu hubungan dimana terdapat suatu kontrak yang mengatur satu orang atau banyak orang sebagai bagian dari prinsipal dan memerintah pihak lain yang disebut dengan agen (Panda, 2017). Dimana mereka (pihak prinsipal) menyuruh atau memberikan wewenang kepada pihak agen untuk melakukan suatu jasa sebaik mungkin, sehingga prinsipal menginginkan hasil yang terbaik. Dalam hal ini hasil terbaik di dapat apabila pihak prinsipal dan agen memiliki tujuan bisnis yang sama, sehingga bisa mendukung tujuan masing-masing kepentingan.Oleh karena itu sebelum melakukan kontrak antara pihak prinsipal dan agen sebaiknya di sampaikan terlebih dahulu apa saja visi, misi dan tujuan secara jelas, sehingga bisa menemukan solusi bersama apabila terdapat perbedaan antara keduanya (Mubarok, 2017).

Teori keagenan ini diperluas lagi dalam hal konsep teorinya dimana muncul atas dasar perluasan antara pihak satu dengan pihak yang lain. Satu pihak menjadi seorang prinsipal dan pihak lainnya menjadi agen. Seorang agen akan melaksanakan suatu pekerjaan / jasa sesuai dengan tugas-tugas yang telah tertuang dalam kontrak, sedangkan prinsipal akan membuat kontrak yang berisikan tugas-tugas kepada agen dan disertai dengan jelas imbalan yang akan didapat bagi seorang agen (Dong, 2021). Jadi seorang prinsipal memberikan otoritas penuh kepada agen untuk melakukan tanggungjawabnya yang sesuai dengan isi kontraknya, dan bagi seorang agen bekerja dengan sungguh-sungguh sesuai dengan isi kontraknya sangat diperlukan untuk mendapatkan hasil yang diinginkan oleh prinsipal. Agen tentu saja harus sadar bahwa apabila hasilnya sesuai dengan keinginan dari prinsipal maka untuk jangka waktu kedepannya masih bisa dipercaya untuk melakukan kontrak yang lainnya (Pergiwati, 2019).

Perbedaan pendapat antara prinsipal dan agen juga tidak bisa dihindari, dimana mereka juga bertindak atas dasar kemauannya sendiri-sendiri. Sebagai contohnya para wirausaha yakni sebagai pelaku ekonomi (prinsipal) memberikan wewenang kepada pihak lain (agen) untuk melakukan kegiatan produksi (Stansbury, 2020). Dimana para wirausaha mengirimkan bahan mentah yang dikirmkan kepada pelaku produksi (agen), mereka tentu saja menginginkan hasil yang berkualitas terbaik. Akan tetapi para pelaku produksi juga memperhitungkan jasa yang didapat disertai dengan kualitas yang dihasilkan. Dalam hal ini tentu saja kontrak secara jelas harus dibahas, dimana untuk mendapatkan hasil yang dinginkan oleh para produsen harus disertai dengan jasa yang pantas bagi pelaku produksi(agen) (Ansharullah, 2018).Berdasarkan hal tersebut maka hubungan keagenan antara kedua belah pihak ini akan berjalan secara maksimal.

\section{Biaya Ekspedisi}

Secara umum biaya ekspedisi di definisikan sebagai suatu harga atau ongkos atas pengiriman surat dan barang ataupun segala sesuatu diluar tersebut dari suatu tempat ke tempat yang lainnya. Dalam pengiriman ini tentu saja membutuhkan pihak lain untuk melakukan suatu pekerjaan, sehingga juga menimpulkan hubungan keagenan.Para pelaku bisnis online yang bertindak sebagai prinsipal sedangkan jasa ekspedisi sebagai pihak agen yang akan melaksankan tugasnya (Agrawal, 2018). Pengiriman biasanya dilakukan dari wilayah tertetu ke wilayah lain yang menjadi tujuan bisa juga dilakukan antar negara. Sebagai contohnya pengiriman dari kota Solo yang ingin mengirimkan barang ke kota Jakarta mempunyai biaya ekspedisi yang jauh lebih murah dibandingkan pengiriman dari kota Solo ke kota Palembang. Jadi perhitungan jarak tempuh dan armada yang digunkan juga mempengaruhi besar kecilnya biaya ekspedisi ini (Merida, 2018). 
Biaya ekspedisi pada umumnya dihitung berdasarkan berat barang dan jarak tempuh kota yang menjadi tujuannya. Dalam definisi yang disebutkan di depan jadi semakin ringan barang yang akan dikirm maka ongkos kirimnya juga akan semakin murah dan semaki berat maka ongkos kirimnya juga akan semakin mahal (Pradana, 2019). Dalam hal ini tentu saja para pelaku bisnis harus mempunyai kriteria sendiri dalam pemilihan ekspedisinya. Pemilihan jasa ekspedisi yang bisa tepercaya untuk menjaga kualitas barang kiriman mempunyai salah satu alasan pemilihannya. Alasan pemilihan yang berikutnya adalah mengenai ongkos kirim dimana semakin murah ongkos kirimnya maka semakin diminati para pelaku bisnis online shop. Kecepatan pengiriman juga menjadi pertimbangan dalam pemilihan jasa ekspedisi, jadi semakin cepat pengirimannya maka para pelaku bisnis akan lebih memilihnya (Setyowiseso, 2018).

Kualitas barang yang tidak rusak ataupun hilang pada saat pengiriman menjadi salah perhatian utama bagi pelaku bisnis online shop, dimana mereka tentu mengirimkan barang dengan kualitas terbaik ke pelanggan (Lesmana, 2019). Kriteria pemilihan ini menjadi wajib dipenuhi, sehingga mereka tinggal menentukan ke kriteria yang kedua dan ketiga.(Nugroho, 2019) Pada kriteria kedua dan ketiga sebenarya berkaitan dalam segi ongkos kirim dan kecepatan pengiriman. Ongkos kirim murah tentu saja kecepatan pengirimannya lama sedangkan ongkos kirim yang mahal kecepatan pengirimannya kilat. Oleh karena itu para pelaku bisnis harus memperhatikan dengan tarif yang sama antar jasa ekspedisi mana yang pengirimannya paling cepat. Pengiriman barang juga harus disesuaikan dengan kebutuhan pelanggan dimana dia menginginkan barang tersebut cepat sampai atau santai dalam hal pengiriman.

\section{Biaya Bahan Baku}

Dalam industri apapun pasti memerlukan bahan baku, dimana dipergunakan sebagai modal awal produksi yang dipergunakan untuk bisa memproduksi barang mentah menjadi barang jadi (Lahu, 2017). Sebagai contoh dalam bisnis konveksi pakaian tentu saja memerlukan bahan baku berupa kain, sehingga setelah masuk kepada penjahit tentu bisa diselesaikan menjadi baju. Dalam dunia bisnis para pengusaha akan berusaha mencari bahan baku yang sesuai dengan kualitas yang dibutuhkan dengan harga yang sesuai anggarannya. Mereka tentunya bisa memperkiraan jenis pasar yang akan di jual, sehingga mereka bisa menempatkan di pasar mana produknya akan dijual. Misalkan mereka akan menjual produk yang biasa dengan harga pasar murah, otomatis harus menjual di pasar traditional. Bahan baku yang digunakan bisa saja berasal dari pembelian lokal, impor ataupun dari pengelolaannya sendiri, dengan demikian tergantung kebutuhan dari masing-masing pengusaha.

Berdasarkan dari yang sudah dijelaskan sebelumnya, sehingga bisa dikatakan bahwa segala sesuatu biaya yang dikeluarkan untuk bisa memperoleh bahan baku yang siap pakai disebut dengan biaya bahan baku. Dalam hal ini biaya bahan baku juga termasuk biaya pengiriman (angkut), operasional maupun penyimpanan (Lahu, 2017). Sehingga biaya bahan baku memiliki peranan yang sangat penting bagi suatu usaha, tentu saja pemilihan bahan baku yang bagus paling diutamakan. Secara umum biaya bahan baku dibedakan menjadi dua, yakni biaya bahan baku langsung dan biaya bahan baku tidak langsung

Biaya bahan baku langsung merupakan jenis komponen biaya yang dikeluarkan pada seluruh bahan dimana akan membentuk suatu bagian yang sifatnya integral atas pemakainnya sehingga manfaatnya signifikan dirasakan setelah menjadi barang jadi. Sedangkan biaya bahan baku tidak langsung adalah jenis komponen biaya dimana semua biayanya dikeluarkan untuk pemenuhan akan tetapi penggunannya diperlukan untuk menyelesaikan suatu produk dengan skala yang cenderung kecil (Lahu, 2017). Oleh sebab itu maka untuk bahan baku ini pengukurannya akan sangat sulit sekali dinilai apabila hanya menggunakan skala per unit produk saja.

\section{Biaya Tenaga Kerja}

Dalam suatu industri ataupun dalam sebuah perusahaan tentu saja memerlukan biaya untuk membayar para pekerja dan pegawai yang ada pada pihaknya, dimana ini adalah definisi tenaga kerja secara umum. Biaya tenaga kerja atau imbalan balas jasa yang diberikan oleh perusahaan dibedakan menjadi dua yakni gaji dan upah (Beladi, 2020) . Gaji merupakan suatu bentuk imbalan dari perusahaan untuk para tenaga kerja tetap, sehingga tenaga kerja yang di berikan imbalan ini sudah tentu menjadi karyawan dalam perusahaan. Sedangkan upah adalah suatu imbalan yang di berikan oleh perusahaan/ pemberi kerja dimana orang tersebut bukan menjadi karyawan tetapnya. Sehingga jelas sekali perbedaan yang mendasar antara gaji dan upah, dimana masih banyak masyarakat yang salah mengartikan (Marinoudi, 2019).

Biaya tenaga kerja dapat menjadi salah satu biaya konversi dalam sisi biaya overhead pabrik dalam hal ini menjadi salah satu konversi dalam rangka biaya yang diperlukan dalam hal untuk mengubah barang mentah menjadi barang jadi. Disamping itu biaya tenaga kerja juga adalah salah satu komponen yang paling besar dalam rangka operasional perusahaan. Sebelum membahas biaya tenaga kerja kita juga perlu mengetahui batasan dan cara klasifikasinya, oleh karena itu para pengusaha harus benar-benar cermat dalam memperhitungkannya (Chandran, 2018). Dalam rangka hubungannya dengan produk, biaya tenga kerja dibedakan menjadi dua yakni biaya tenaga kerja langsung dan biaya tenega kerja tidak langsung. Biaya kerja langsung merupakan suatu biaya yang dikeluarkan dalam rangka membayar tenaga kerja yang ikut serta secara langsung pada proses pengolahan baha baku menjadi barang setengah jadi dan barang jadi dalam aktivitas produksi. Sedangkan biaya tenaga kerja tidak langsung adalah biaya yang dikeluarkan untuk membayar tenaga kerja yang tidak langsung terlibat dalam proses produksi. 


\section{A. Jenis dan Sumber Data}

\section{METODE PENELITIAN}

Penelitian ini menggunakan metode kuantitatif yang pengukuranya dengan skala likert, dimana jenis data yang digunakan adalah primer. Sumber data diperoleh dengan menyebar kuesioner kepada para responden dalam hal ini adalah pelaku/pedagang bisnis online shop di kota surakarta.

\section{B. Populasi dan Sampel Penelitian}

Penelitian ini menggunakan data 65 pelaku/pedagang bisnis online shop yang ada di kota surakarta. Metode pemilihan sampel yang digunakan adalah dengan menggunkan metode purposive sampling dengan kriteria sebagai berikut :

1. Responden adalah pelaku bisnis online shop di kota Surakarta

2. Responden memiliki toko online shop di sosial media (Instagram, Facebook, maupun E-Commerce lainnya)

3. Responden mempunyai omset di bawah 200 Juta pertahun

4. Responden hanya diperkenankan mempunyai kesempatan sekali dalam pengisian kuesioner

\section{Pengukuran Variabel}

Analisis data yang digunakan dalam penelitian ini adalah dengan menggunakan model analisis regresi berganda. Dalam analisi regresi berganda digunakan dalam hal untuk mengukur hubungan antara dua variabel atau lebih jelas arah hubungannya jelas antara variabel dependen dan variabel independen. Model atas pengujian hipotesis yang digunakan dalam penelitian ini adalah sebagai berikut :

$\mathrm{Y}=\mathrm{a}+\mathrm{b} 1 \mathrm{X} 1+\mathrm{b} 2 \mathrm{X}_{2}+\mathrm{b} 3 \mathrm{X} 3+\varepsilon$

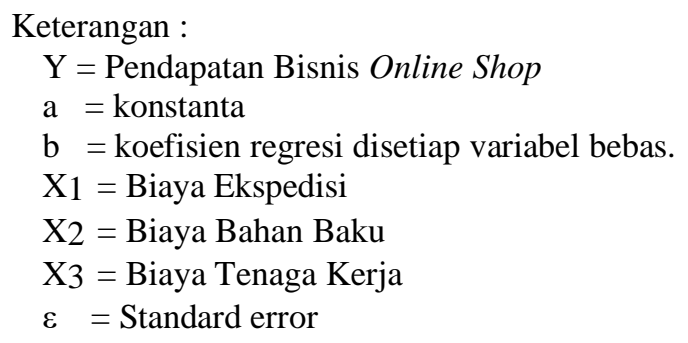

\section{Pengembangan Hipotesis}

\section{Biaya Ekspedisi}

Jenis komponen biaya ini sangat dibutuhkan dalam kegiatan online shop dimana hasil produksinya bisa sampai kepada konsumen, Biaya ekspedisi memanglah bukan biaya yang besar, akan tetapi manfaatnya sangat besar dimana benar-benar harus diperhatikan oleh para pelaku bisnis online shop.Pengaruh biaya ekspedisi terhadap omset penjualan online shop belum pernah diteliti oleh peneliti sebelumnya, oleh karena itu hasilnya masih menarik untuk diketahui. Sehingga hipotesisnya dapat dirumuskan :

\section{H$_{1}$ : Biaya Ekspedisi Berpengaruh Positif dan Signifikan Terhadap Pendapatan Bisnis Online Shop}

\section{Biaya Bahan Baku}

Dalam dunia industri komponen biaya ini sangat dibutuhkan dan harus dilakukan perencanaan yang matang untuk prosesnya, banyak sekali industri yang gagal karena tidak bisa merencanakan dengan baik jenis komponen biaya ini. Pada biaya bahan baku ini masih banyak penelitian yang belum konsisten atas hasilnya sehingga menarik untuk diteliti. Penelitian (Suartawan dan Purbadharmaja 2017) menyatakan bahwa biaya bahan baku berpengaruh positif dan signifikan terhadap pendapatan. Akan tetap berbeda dengan penelitian dari (Nayaka dan Kartika, 2018) yang menyatakan bahwa biaya bahan baku berpengaruh positif akan tetapi tidak sugnifikan

\section{$\mathrm{H}_{2}$ :Biaya Bahan Baku Berpengaruh Positif dan Signifikan Terhadap Pendapatan Bisnis Online Shop}

\section{Biaya Tenaga Kerja}

Jenis komponen biaya ini yang paling dirasakan oleh sektor industri, karena komponen biaya ini juga termasuk pengeluaran yang terbesar. Banyak sekali perusahaan yang mempunyai tenaga kerja yang minim, sehingga pekerjaannya menjadi kacau, karena mereka benar-benar mau meminimalisir pengeluaran. Penelitian dari Wiharnata (2021) menyatakan bahwa biaya tenaga kerja berpengaruh positif dan signifikan terhadap pendapatan akan tetapi berbeda dengan peneitian dari Elvira (2021) yang menyatakan bahwa tenaga kerja berpengaruh positif akan tetapi tidak sigifikan dengan pendapatan.

\section{$\mathrm{H}_{3}$ :Biaya Tenaga Kerja Berpengaruh Positif dan Signifikan Terhadap Pendapatan Bisnis Online Shop}




\section{HASIL DAN PEMBAHASAN}

\section{A. Statistik Deskriptif}

Tabel 1

Hasil Uji Statistik Deskriptif

\begin{tabular}{lccccc}
\hline & N & Minimum & Maximum & Mean & Std Deviation \\
Biaya Ekspedisi & 65 & 16 & 35 & 29.6 & 3.586 \\
Biaya Bahan Baku & 65 & 16 & 32 & 27 & 3.213 \\
Biaya Tenaga Kerja & 65 & 19 & 40 & 34.34 & 3.815 \\
Pendapatan & 65 & 21 & 35 & 30.34 & 2.939 \\
\hline Valid N (listwise) & 65 & \multicolumn{5}{c}{} & \\
\hline Sumber : Data yang Diolah, 2021 &
\end{tabular}

Berdasarkan hasil output SPSS pada tabel 1 diatas maka dapat dijelaskan :

1. Data yang digunakan dalam penelitian ini adalah sebanyak 65

2. Nilai minimum biaya ekspedisi adalah 16 , nilai maximum sebesar 35 , nilai mean sebesar 29.60 dan nilai deviation standart sebesar 3,586

3. Nilai minimum biaya bahan baku adalah 16 , nilai maximum sebesar 32 , nilai mean sebesar 27 dan nilai deviation standart adalah sebesar 3,213

4. Nilai minimum biaya tenaga kerja adalah 19 , nilai maximum adalah 40 . nilai mean adalah 34,34 dan nilai deviation standart adalah 3,815

5. Nilai minimum pendapatan adalah 21 , nilai maximum adalah 35 , nilai mean adalah 30,34 dan nilai deviation standart adalah 2,939

B. Uji Regresi Linier Berganda

Tabel 2

Hasil Uji Regesi Linier Berganda

\begin{tabular}{lccccc}
\hline \multirow{2}{*}{ Model } & \multicolumn{3}{c}{ Unstandardized Coefficients } & \multicolumn{2}{c}{ Standardized Coefficients } \\
& $B$ & Std & Beta & $t$ & Sig \\
& & Error & & & \\
\hline (Constant) & 7,334 & 2,456 & & 3,567 & 0,000 \\
Biaya Ekspedisi & 0,074 & 0,135 & 0,145 & 0,697 & 0,001 \\
Biaya Bahan Baku & 0,035 & 0,095 & 0,071 & 0,667 & 0,000 \\
Biaya Tenaga Kerja & 0,045 & 0,119 & 0,687 & 4,675 & 0,000 \\
\hline
\end{tabular}

Sumber : Data yang Diolah, 2021

Berdasarkan dari pengujian regresi liner berganda diatas maka hasil dari pengujian hipotesis bisa di uraikan sebagai berikut:

1. Pengaruh biaya ekspedisi terhadap pendapatan online shop Surakarta

Hasil dari analisis data dari pengujian menunjukkan bahwa biaya ekspedisi menghasilkan nilai $t_{\text {hitung }}=0,697<\mathrm{t}_{\text {tabel }}=$ 2,650 dan nilai signifikansinya $0,001<0,005$ maka berdasarkan hasil tersebut bisa diambil kesimpulan $\mathrm{H}_{\mathrm{O}}$ diterima sehingga hipotesis pertama yang menyatakan bahwa biaya ekspedisi berpengaruh positif dan signifikan terhadap pendapatan online shop di kota Surakarta. Hasil dari penelitian ini juga membuktikan bahwa walaupun biaya ekspedisi ini kadangkala sering dianggap tidak seius oleh pelaku online shop akan tetapi dengan hasil temuan ini bisa lebih diperhatikan. Para pelaku online shop hendaknya bisa lebih seksama dalam hal memilih jasa ekspedisi yan digunkan sehingga pendapatannya juga akan lebih maksimal. Penelitian dengan variabel biaya ekspedisi terhadap pendapatan dalam hal ini belum ada penelitian sebelumnya yang melakukan, sehingga dalam penelitia ini tidak bisa menampilkan penelitian sebelumnya yang mendukung hasil ini.

2. Pengaruh biaya bahan baku terhadap pendapatan online shop Surakarta

Berdasarkan hasil dari analisis data diatas maka diperoleh biaya bahan baku menunjukkan nilai $t_{\text {hitung }}=0,667<\mathrm{t}_{\text {tabel }}$ $=2,650$ dan nilai signifikansinya adalah $0,000<0,005$ maka dari hasil tersebut bisa diambil kesimpulan $\mathrm{H}_{0}$ diterima sehingga hipotesis kedua yang menyatakan biaya bahan baku berpengaruh positif dan signifikan terhadap pendapatan online shop di kota Surakarta diterima. Hasil ini sejalan dengan penelitian dari Nayaka dan kartika (2018) yang menyatakan bahwa biaya bahan baku berpengaruh positif dan signifikan terhadap pendapatan di perusahaan manufaktur 
yang terdaftar di BEI. Penelitian ini juga mendukung penelitian dari Reza (2020) yang menyatakan bahwa biaya bahan baku berpengaruh positif dan signifikan terhadap pendapatan di perusahaan swasta.

\section{Pengaruh biaya tenaga kerja terhadap pendapatan online shop Surakarta}

Hasil dari analisis data menunjukka bahwa biaya tenaga kerja menghasilkan nilai $t_{\text {hitung }}=4,675<\mathrm{t}_{\text {tabel }}=2,650$ dan nilai signifikkansinya adalah $0,000<0,005$ maka dari hasil tersebut bisa diambil kesimpulan $\mathrm{H}_{0}$ diterima dan hipotesis ketiga yang menyakan biaya tenaga kerja berpengaruh positif dan signifikan terhadap pendapatan di kota Surakarta diterima.Hasil dari penelitian ini mendukung penelitian dari Wiharnata (2021) yang menyatakan bahwa biaya tenaga kerja berpengaruh positif dan signifikan terhadap pendapatan online shop kota Surakarta

\section{KESIMPULAN}

Berdasarkan dari hasil analisis data diatas maka dalam penelitian ini dapat ditarik kesimpulan sebagai berikut :

1. Biaya ekspedisi berpengaruh positif dan signifikan terhadap pendapatan online shop di Surakarta. Hal ini berarti maka semakin baik pelaku online shop memperhatikan biaya ekspedisi maka pendapatannya juga akan meningkat

2. Biaya bahan baku berpengaruh positif dan signifikan terhadap pendapatan online shop di Surakarta. Penelitian ini membuktikan bahwa apabila pelaku memperhatikan bahan baku yang baik maka pendapatanya akan meningkat.

3. Biaya tenaga kerja berpengaruh positif dan signifikan terhadap pendapata online shop di Surakarta. Hal ini membuktikan bahwa apabila biaya tenaga kerja ini benar-benar diperhatikan maka pendapatannya juga akan meningkat.

\section{Keterbatasan}

1. Penelitian ini hanya menguji pelaku online shop di kota Surakarta, sehingga hasil bisa berbeda apabila menguji di daerah lain.

2. Waktu yang digunakan dalam penelitian ini hanya singkat, sehingga pemilihan sampelnya kurang lengkap

3. Masih adanya variabel lain yang memungkinkan menarik untuk diteliti

Saran

1. Penelitian selanjutnya juga meguji di daerah yang lain, sehingga komplektisitas permasalahan lebih banyak dan hasil penelitiannya juga bisa berbeda

2. Waktu untuk meneliti sebaiknya ditambah untuk penelitian selanjutnya, sehingga bisa memaksimalkan sampel yang akan diuji

3. Variabel penelitian bisa ditambah sesuai dengan situasi yang berbeda di setiap daerah/kota

\section{DAFTAR PsUSTAKA}

Alalwan, A. A., Rana, N. P., Dwivedi, Y. K., \& Algharabat, R. (2017). Social media in marketing: A review and analysis of the existing literature. Telematics and Informatics, 34(7), 1177-1190.

Ansharullah, A., Natasha, H., \& Indra, A. M. (2018). Pemberdayaan Pelaku Ekonomi Sektor Melalui Peningkatan Pemahaman Konsep Wisata Syariah. Jurnal Pemberdayaan Masyarakat Madani (JPMM), 2(2), 224-236.

Appel, G., Grewal, L., Hadi, R., \& Stephen, A. T. (2020). The future of social media in marketing. Journal of the Academy of Marketing Science, 48(1), 79-95.

Beladi, H., Cheng, C., Hu, M., \& Yuan, Y. (2020). Unemployment governance, labour cost and earnings management: Evidence from China. The World Economy, 43(10), 2526-2548.

Chandran, S. R. (2018). Impact of agro machinery service centres on labour cost in paddy cultivation. IMPACT: International Journal of Research in Humanities, Arts and Literature, 6(01), 265-268.

Dong, J. Q., Karhade, P. P., Rai, A., \& Xu, S. X. (2021). How firms make information technology investment decisions: Toward a behavioral agency theory. Journal of Management Information Systems, 38(1), 29-58.

Elvira, A. A., Hindarti, S., \& Khoiriyah, N. (2021). Usahatani Porang Dan Kontribusinya Terhadap Pendapatan Keluarga (Study Kasus: Di Desa Selur, Kecamatan Ngrayun, Kabupaten Ponorogo). Jurnal Sosial Ekonomi Pertanian dan Agribisnis, 8(3).

Haus-Reve, S., Fitjar, R. D., \& Rodríguez-Pose, A. (2019). Does combining different types of collaboration always benefit firms? Collaboration, complementarity and product innovation in Norway. Research Policy, 48(6), 1476-1486.

Johansson, N., \& Henriksson, M. (2020). Circular economy running in circles? A discourse analysis of shifts in ideas of circularity in Swedish environmenta policy. Sustainable Production and Consumption, 23, 148-156.

Koziel, S., \& Bekasiewicz, A. (2017). Expedited simulation-driven design optimization of UWB antennas by means of response features. International Journal of RF and Microwave Computer-Aided Engineering, 27(6), e21102.

Lahu, E. P., \& Sumarauw, J. S. (2017). Analisis Pengendalian Persediaan Bahan Baku Guna Meminimalkan Biaya Persediaan Pada Dunkin Donuts Manado. Jurnal EMBA: Jurnal Riset Ekonomi, Manajemen, Bisnis Dan Akuntansi, 5(3)

Marinoudi, V., Sørensen, C. G., Pearson, S., \& Bochtis, D. (2019). Robotics and labour in agriculture. A context consideration. Biosystems Engineering, 184, 111-121.

Merida, D. R. (2018). Pelaksanaan Perlindungan Konsumen atas Kehilangan Barang pada Pengiriman oleh Jasa Ekspedisi Barang Berdasar Undang-undang Nomor 8 Tahun 1999 Tentang Perlindungan Konsumen (Studi pada Kantor Pos Solo). Digital Library UNS

Mubarok, R., Santoso, B., \& Njatrijani, R. (2017). Pertanggungjawaban Agen Branchless Banking terhadap Nasabah Branchless Banking (Hubungan Hukum Antara Agen-Prinsipal dan Konsumen). Diponegoro Law Journal, 6(2), 1-12.

Nugroho, T. S. P. (2018). CALCULATION OF PRODUCTION PRICE ANALYSIS IN CV PELANGI ADVERTISING. International Journal of Economics, Business and Accounting Research (IJEBAR), 2(01).

Nugroho, T. S. P., Adelina, N., \& Wibowo, T. W. P. (2019). ANALISIS KOMPREHENSIF TERHADAP PENUMBUHAN JIWA ENTREPRENEURSHIP SEBAGAI PENGUATAN EKONOMI MASYARAKAT (Studi Kasus Pada Masyarakat Sekarisidenan Surakarta). EDUSAINTEK, 3.

Pakkanen, J., Brysbaert, A., Turner, D., \& Boswinkel, Y. (2020). Efficient three-dimensional field documentation methods for labour cost studies: Case studies from archaeological and heritage contexts. Digital Applications in Archaeology and Cultural Heritage, $17, \mathrm{e} 00141$. 
Palmer, K., Tate, J. E., Wadud, Z., \& Nellthorp, J. (2018). Total cost of ownership and market share for hybrid and electric vehicles in the UK, US and Japan. Applied energy, 209, 108-119.

Panda, B., \& Leepsa, N. M. (2017). Agency theory: Review of theory and evidence on problems and perspectives. Indian Journal of Corporate Governance, 10(1), $74-95$.

Pradana, T. A. (2019). APLIKASI ALGORITMA DIJKSTRA DAN ALGORITMA FLOYD WARSHALL DALAM EKSPEDISI BARANG 1 DAN EKSPEDISI BARANG 2 DI KOTA SURAKARTA (Doctoral dissertation, Universitas Islam Indonesia)

Rosdiana, Y. M., Iriyadi, I., \& Wahyuningsih, D. (2020). Pendampingan Peningkatan Efisiensi Biaya Produksi UMKM Heriyanto Melalui Analisis Biaya Kualitas. Jurnal Abdimas Dedikasi Kesatuan, 1(1), 1-10.

REZA, M. F. (2020). EFEKTIFITAS BIAYA BAHAN BAKU PADA USAHA SOUVENIR MATA KAYU DALAM MENINGKATKAN PENDAPATAN USAHA MENURUT EKONOMI ISLAM (Doctoral dissertation, UNIVERSITAS ISLAM NEGERI SULTAN SYARIF KASIM RIAU).

Sari, W. N. I., \& Mardiana, L. (2019). Analisis perhitungan tarif jasa ekspedisi menggunakan metode cost plus pricing dengan pendekatan full costing (studi pada pt. rapi trans logistik indonesia). In PROSIDING SEMINAR NASIONAL CENDEKIAWAN (pp. 2-86)

Setyowiseso, B., \& Sutopo, S. (2018). ANALISIS PENGARUH MANAJEMEN HUBUNGAN PELANGGAN TERHADAP LOYALITAS PELANGGAN MELALUI KEPUASAN PELANGGAN SEBAGAI VARIABEL INTERVENING (Pada Pelanggan Jasa Ekspedisi Pengiriman Barang TIKI di Kecamatan Banjarsari, Kota Solo) (Doctoral dissertation, Fakultas Ekonomika dan Bisnis).

Shah, S., \& Mishra, A. K. (2018). Review on global practice of housing demand fulfilment for low income group people. NOLEGEIN Journal of Business Ethics, Ethos \& CSR, 1(2), 5-16

Situmeang, R. R. (2018). Dampak Bisnis Online dan Lapangan Pekerjaan terhadap Peningkatan Pendapatan Masyarakat (Studi Kasus Jasa Bisnis Online Transportasi Grab di Kota Medan). Asian Journal of Innovation and Entrepreneurship, 3(03), 319-335.

Stansbury, A., \& Summers, L. (2020). Declining worker power and American economic Performance. Brookings Papers on Economic Activity.

Suartawan, I. K., \& Purbadharmaja, I. B. (2017). Pengaruh Modal Dan Bahan Baku Terhadap Pendapatan Melalui Produksi Pengrajin Patung Kayu Di Kecamatan Sukawati Kabupaten Gianyar. E-Jurnal Ekonomi Pembangunan Universitas Udayana, 6(9).

Susanto, R. (2018). Raw material inventory control analysis with economic order quantity method. In IOP Conference Series: Materials Science and Engineering (Vol. 407, No. 1, p. 012070). IOP Publishing.

Tosello, G., Charalambis, A., Kerbache, L., Mischkot, M., Pedersen, D. B., Calaon, M., \& Hansen, H. N. (2019). Value chain and production cost optimization by integrating additive manufacturing in injection molding process chain. The International Journal of Advanced Manufacturing Technology, 100(1-4), 783795.

Weldy, T. G. (2018). Traditional, blended, or online: Business student preferences and experience with different course formats. E-Journal of Business Education and Scholarship of Teaching, 12(2), 55-62.

Wiharnata, A. I., Sumardi, S., \& Saparto, S. (2021). PENGARUH BIAYA SARANA PRODUKSI DAN TENAGA KERJA TERHADAP PENDAPATAN USAHATANI PADI INPARI. Jurnal Pertanian Agros, 23(1), 121-133. 